\title{
Talus localized osteochondromas: Treatment management and mid-term outcomes - Case series
}

\author{
Talus yerleşimli osteokondromlar: Tedavi yönetimi ve orta dönem sonuçlar - Olgu serileri
}

\author{
Recep Öztürk, MD ${ }^{1}$, İsmail Burak Atalay, $\mathrm{MD}^{1} \odot$, Ali Ekber Yapar, $\mathrm{MD}^{1} \odot$, Galip Beltir, $\mathrm{MD}^{1} \odot$, \\ Şefik Murat Arıkan, $\mathrm{MD}^{2}$ (1), Bedii Şafak Güngör, $\mathrm{MD}^{1}$ (i)
}

'Department of Orthopedics and Traumatology, Dr. Abdurrahman Yurtaslan Ankara Oncology Training and Research Hospital, Ankara, Turkey ${ }^{2}$ Department of Orthopedics and Traumatology, Gazi University Faculty of Medicine, Ankara, Turkey

\begin{abstract}
Objectives: This study aims to define the demographic and clinical findings of patients with talus localized osteochondroma, to present treatment management and mid-term results.

Patients and methods: The study included 10 patients (4 males, 6 females; mean age $31.9+19.5$ years; range, 11 to 70 years) with osteochondroma of the talus who were admitted to our center between January 2008 and December 2015. Clinical findings, treatment methods, and clinical outcomes were retrospectively evaluated. All patients were followed-up for at least two years.
\end{abstract}

Results: The most frequent localization was anterior of the talus $(70 \%, \mathrm{n}=7)$. The mean tumor size was $2.4 \pm 1.4 \mathrm{~cm}$ (range, $1-5 \mathrm{~cm})$. When the relationship between tumor diameter and age was analyzed, no statistically significant correlation was detected $(\mathrm{p}=0.973)$. Besides, no statistically significant difference was found between the genders in terms of tumor diameters $(\mathrm{p}=0.584)$. The most common symptoms were pain, swelling, and restricted movements. The mean duration of postoperative follow-up was 48.1 \pm 27.7 months (range, 24-114 months). All patients underwent complete surgical excision. None of the patients developed recurrence or complication related to the treatment of osteochondroma.

Conclusion: Talus localized osteochondromas are often symptomatic and more common in adults. Also, they are more common in females. The ideal treatment approach is resection of the tumor. When rigorous surgical excision is performed, recurrence rates are low with satisfactory outcomes.

Keywords: Exostosis, osteochondroma, talus.

\section{Öz}

Amaç: Bu çalışmada, talus yerleşimli osteokondromu olan hastaların demografik ve klinik bulguları tanımland, tedavi yönetimi ve orta dönem sonuçları sunuldu.

Hastalar ve yöntemler: Çalışmaya Ocak 2008 ve Aralık 2015 tarihleri arasında merkezimize kabul edilen talus osteokondromlu 10 hasta (4 erkek, 6 kadın; ort. yaş 31.9+19.5 yıl; dağılım, 11-70 yıl) dahil edildi. Klinik bulgular, tedavi yöntemleri ve klinik sonuçlar retrospektif olarak değerlendirildi. Tüm hastalar en az iki yıl takip edildi.

Bulgular: En sık yerleşim yeri talus anteriyoru idi (\%70, $\mathrm{n}=7$ ). Ortalama tümör boyutu $2.4 \pm 1.4 \mathrm{~cm}$ (dağılım, $1-5 \mathrm{~cm}$ ) idi. Tümör çapı ile yaş arasındaki ilişki incelendiğinde, istatistiksel olarak anlamlı ilişki saptanmadı $(\mathrm{p}=0.973)$. Ayrıca, cinsiyetler arasında tümör çapları açısından istatistiksel olarak anlamlı bir farklılık bulunmad $1(\mathrm{p}=0.584)$. En yaygın semptomlar ağrı, şişlik ve hareket kısıtlılığı idi. Ameliyat sonrası ortalama takip süresi $48.1 \pm 27.7$ ay (dağılım, 24-114 ay) idi. Tüm hastalara total cerrahi eksizyon yapıldı. Hiçbir hastada nüks veya osteokondrom tedavisi ile ilgili komplikasyon gelişmedi.

Sonuç: Talus yerleşimli osteokondromlar genellikle semptomatiktir ve erişkinlerde daha yaygındır. Ayrıca, kadınlarda daha yaygındır. İdeal tedavi yaklaşımı tümörün rezeksiyonudur. Titiz cerrahi eksizyon uygulandı̆̆ında, nüks oranları tatmin edici sonuçlarla düşüktür.

Anahtar sözcükler: Egzositoz, osteokondrom, talus.

Received: June 10, 2019 Accepted: July 10, 2019 Published online: October 24, 2019

Correspondence: Recep Öztürk, MD. Dr. Abdurrahman Yurtaslan Ankara Onkoloji Eğitim ve Araștırma Hastanesi Ortopedi ve Travmatoloji Kliniği, 06200 Yenimahalle, Ankara, Turkey. Tel: +90 505 - 4634794 e-mail: ozturk_recep@windowslive.com 
Osteochondromas (exostoses) are the most common benign bone tumors and often tend to be localized near the growth plates of long bones that develop by endochondral ossification. The most common sites are distal femur, proximal tibia, and proximal humerus. ${ }^{[1,2]}$

Osteochondromas are rarely localized in the tubular bones of the hand and foot and the bones resulting from membranous ossification..$^{[1,3]}$ Talus location is very rare (less than $0.5 \%$ ). ${ }^{[4]}$ Talus placement of osteochondromas are important because even a small tumor can cause significant biomechanical imbalance leading to pain and impaired function translated as early presentation and detection of the abnormality. ${ }^{[5]}$

In general, osteochondroma is first diagnosed at ages six to 20 years with rapid growth, although talus localized osteochondromas have been diagnosed in adults in most cases $(61.5 \%){ }^{[1,4,6-10]}$ In this study, we aimed to define the demographic and clinical findings of patients with talus localized osteochondroma, to present treatment management and mid-term results.

\section{PATIENTS AND METHODS}

This retrospective study included 10 patients (4 males, 6 females; mean age 31.9+19.5 years; range,
11 to 70 years) with talus localized exostosis that were managed in Orthopaedic Oncology Clinic of Dr Abdurrahman Yurtaslan Ankara Oncology Trainig and Research Hospital between January 2008 and December 2015. Patients with a minimum follow-up of two years and a final diagnosis of osteochondroma were included. A written informed consent was obtained from each patient. The study was conducted in accordance with the principles of the Declaration of Helsinki.

Clinical diagnosis of exostosis was established after clinical evaluation and assessment of bilateral radiography of the extremity. Magnetic resonance imaging (MRI) was ordered in all patients for differential diagnosis to assess the accompanying lesion more clearly, to make a three-dimensional assessment of the lesion, and to establish the relationship with the adjacent structure for planning the operation.

In all patients, infusion was carried out over the swelling and the tumor was exposed from the surroundings. The tumor was then extraperiostally excised and sent for histopathological examination by an experienced musculoskeletal system pathologist.

TABLE I

Baseline characteristics $(n=10)$

\begin{tabular}{|c|c|c|c|c|c|}
\hline & $\mathrm{n}$ & $\%$ & Mean $\pm S D$ & Median & Min-Max \\
\hline Age (year) & & & $31.9 \pm 19.6$ & 24.5 & $11.0-70.0$ \\
\hline \multicolumn{6}{|l|}{ Age groups } \\
\hline$\leq 18$ years & 3 & 30.0 & & & \\
\hline$>18$ years & 7 & 70.0 & & & \\
\hline \multicolumn{6}{|l|}{ Gender } \\
\hline Male & 4 & 40.0 & & & \\
\hline Female & 6 & 60.0 & & & \\
\hline \multicolumn{6}{|l|}{ Location } \\
\hline Neck (anterior) & 7 & 70.0 & & & \\
\hline Body & 3 & 30.0 & & & \\
\hline \multicolumn{6}{|l|}{ Side } \\
\hline Right & 4 & 40.0 & & & \\
\hline Left & 6 & 60.0 & & & \\
\hline \multicolumn{6}{|l|}{ Signs and symptoms* } \\
\hline Restricted movements & 10 & 100.0 & & & \\
\hline Pain & 9 & 90.0 & & & \\
\hline Swelling & 7 & 70.0 & & & \\
\hline Cosmetic deformity & 3 & 30.0 & & & \\
\hline Follow-up time (month) & & & $48.1 \pm 27.7$ & 40.0 & $24.0-114.0$ \\
\hline Diameter (cm) & & & $2.4 \pm 1.4$ & 2.0 & $1.0-5.0$ \\
\hline
\end{tabular}

SD: Standard deviation; Min: Minimum; Max: Maximum; * One patient has multiple symptoms. 
TABLE II

Correlation between age and diameter

\begin{tabular}{lcc}
\hline & \multicolumn{2}{c}{ Diameter } \\
\cline { 2 - 3 } & $r$ & $p$ \\
\hline Age & -0.012 & 0.973 \\
\hline
\end{tabular}

r: Spearman's correlation coefficient

\section{Statistical analysis}

Statistical analysis was performed by IBM SPSS version 22.0 (IBM Corp., Armonk, NY, USA) software. Categorical variables were given as numbers and percentages. Continuous variables were presented with mean \pm standard deviation and median (min-max value) for descriptive analyses. Chi-square tests were used for comparison of categorical variables between groups. The conformity of continuous variables to normal distribution was evaluated using visual (histogram and probability graphs) and analytical methods (Kolmogorov-Smirnov/Shapiro-Wilk tests). Normality analysis revealed that all data sets were not normally distributed. Mann-Whitney U test was used for comparison of data sets which were not normally distributed for the variables. Spearman correlation was used to test the association between diameter and patients' ages. $\mathrm{P}<0.05$ was considered statistically significant.

\section{RESULTS}

Of the patients, $70 \%$ were over the age of 18 years (Table I). One patient had a positive familial history of multiple hereditary exostosis (MHE), while all the others had solitary lesions and presented with primary tumors. The patient with MHE had diffuse lesions in the calcaneus, navicula, metatarsal localization, and also in the long bones of the same extremity.

The mean lesion diameter was $2.4 \mathrm{~cm}$ (range, 1-5 $\mathrm{cm}$ ) and four lesions were right- and six lesions were left-sided (Table I). The most common localization was anterior of the talus (seven cases, 70\%), and the most common signs and symptoms were pain, swelling, and restricted movements.

When the relationship between tumor diameter and age was examined by Spearman correlation analysis, no statistically significant correlation was found $(\mathrm{p}=0.973)$ (Table II).

The median age values of male and female patients were found to be similar $(\mathrm{p}=0.831)$. The median tumor diameter was $2.5 \mathrm{~cm}$ (range, 1-5 cm) in females

TABLE III

Evaluation of patients groups $(n=10)$

\begin{tabular}{|c|c|c|c|c|c|c|c|c|c|c|c|}
\hline & \multicolumn{10}{|c|}{ Gender } & \multirow[b]{3}{*}{$p$} \\
\hline & \multicolumn{5}{|c|}{ Male $(n=4)$} & \multicolumn{5}{|c|}{ Female $(n=6)$} & \\
\hline & $\mathrm{n}$ & $\%$ & Mean $\pm S D$ & Median & Min-Max & $\mathrm{n}$ & $\%$ & Mean $\pm S D$ & Median & Min-Max & \\
\hline Age (year) & & & $25.8 \pm 8.3$ & 24.5 & $17.0-37.0$ & & & $36.0 \pm 24.5$ & 30.0 & $11.0-70.0$ & $0.831 \dagger$ \\
\hline Diameter (cm) & & & $2.0 \pm 0.8$ & 2.0 & $1.0-3.0$ & & & $2.7 \pm 1.6$ & 2.5 & $1.0-5.0$ & $0.584 \dagger$ \\
\hline Location & & & & & & & & & & & $1.000 \ddagger$ \\
\hline Neck & 3 & 75.0 & & & & 4 & 66.7 & & & & \\
\hline Body & 1 & 25.0 & & & & 2 & 33.3 & & & & \\
\hline Side & & & & & & & & & & & $1.000 \ddagger$ \\
\hline Right & 2 & 50.0 & & & & 2 & 33.3 & & & & \\
\hline \multirow[t]{4}{*}{ Left } & 2 & 50.0 & & & & 4 & 66.7 & & & & \\
\hline & \multicolumn{10}{|c|}{ Location } & \\
\hline & \multicolumn{5}{|c|}{ Neck $(n=7)$} & \multicolumn{5}{|c|}{ Body $(n=3)$} & \\
\hline & $\mathrm{n}$ & $\%$ & Mean $\pm S D$ & Median & Min-Max & $\mathrm{n}$ & $\%$ & Mean $\pm S D$ & Median & Min-Max & $p$ \\
\hline Age (year) & & & $35.1 \pm 21.8$ & 25.0 & $15.0-70.0$ & & & $24.3 \pm 13.5$ & 24.0 & $11.0-38.0$ & $0.569 \dagger$ \\
\hline Side & & & & & & & & & & & $0.569 \dagger$ \\
\hline Right & 3 & 42.9 & & & & 1 & 33.3 & & & & \\
\hline Left & 4 & 57.1 & & & & 2 & 66.7 & & & & \\
\hline Diameter (cm) & & & $2.4 \pm 1.4$ & 2.0 & $1.0-5.0$ & & & $2.3 \pm 1.5$ & 2.0 & $1.0-4.0$ & $0.907 \dagger$ \\
\hline
\end{tabular}

SD: Standard deviation; Min: Minimum; Max: Maximum; † Mann-Whitney U test; $\ddagger$ Chi-square test. 
and $2 \mathrm{~cm}$ (range, 1-3 cm) in males. No statistically significant difference was found between the genders in terms of tumor diameters ( $\mathrm{p}=0.584)$ (Table II). Side and settlement characteristics were similar between the genders ( $p>0.05)$. When the tumor characteristics were evaluated according to their location, the median age of the patients with neck and trunk tumors was similar ( $\mathrm{p}=0.569)$. While $57.1 \%$ of the tumors in the neck were on the left, $66.7 \%$ of the tumors in the body were on the left. The involvement of the left side was more frequent both neck and body localizations. And left side involvement rates were similar in these localizations $(\mathrm{p}=1.000)$ (Table III). The median tumor diameter was $2 \mathrm{~cm}$ (range, 1-5 cm) in neck and $2 \mathrm{~cm}$ (range, $1-4 \mathrm{~cm}$ ) in the trunk. No statistically significant difference was found in terms of tumor diameter ( $\mathrm{p}=0.907)$ (Table III).

All patients underwent marginal resection. When accompanying findings of the patients were examined, no intervention was attempted for the other lesions in the extremity of one of the patients. Medical therapy was scheduled for tibiotalar arthritis in one of the patients, and antegrade drilling was performed according to a modified Pritsch classification for the osteochondral defect in another patient. Grafting was carried out with an iliac autogenous graft after the curettage of accompanying simple bone cyst. Histopathologic examination of the curettage material was reported as a simple bone cyst. While movement limitation was observed in all patients, $90 \%$ had pain and $70 \%$ had swelling (Table I).

All patients were followed-up for a mean of 48 months (range, 24-114 months). None of the patients developed recurrence or complication related to the treatment of osteochondroma.

\section{DISCUSSION}

Osteochondromas are the most common benign bone tumors. These tumors are often located near the growth plates of the bones that develop with enchondral ossification. This is due to the deflection of the growth plate, in which several cells from the plate grow as a separate bone stack by centrifugation. Although any bone developed by endochondral ossification is susceptible to this condition, osteochondromas are localized in the metaphysis of long tubular bones in half of the cases. In addition, they are rare in the tubular bones of the hand and foot and the bones developed by intramembranous ossification. Talus location is very rare. In the literature, osteochondromas localized in the talus are reported as case reports. . $^{[1,4,6,11,12]}$
More than $60 \%$ of all osteochondromas occur in male sex. ${ }^{[13]}$ Interestingly, we found a $40 \%$ incidence of talus localized osteochondroma in male patients (Table I).

Andreacchio et al ${ }^{[6]}$ reported that they found a total of 26 cases with osteochondromas, and $61 \%$ of these cases were identified in adults. In our study, $70 \%$ of the patients were over the age of 18 years (Table I). Also, these authors reported that the most common localization was the talus neck $(30 \%)$. The most common localization was the talus neck with a high rate of $70 \%$ in our study as consistent with the literature.

Many reports in the literature state that solitary osteochondroma is more common than MHE associated lesions, and the incidence of MHE is $5-10 \%$ of solitary lesions. In the present study, MHEassociated osteochondroma was found in one of the 10 patients $(10 \%)$.

Clinical examination and direct radiography are the most effective methods for diagnosis. Although solitary osteochondromas are often asymptomatic, it has been reported that localized osteochondromas of the talus present with symptoms of pain, swelling, and restricted movement. ${ }^{[1,4,6,14,15]}$ These findings were the most common three findings in our study (Table I). ${ }^{[16]}$ The pain can be caused by mechanical irritation, fracture of the osteochondroma, and/or presence of intraarticular loose bodies..$^{[4,5,8,12,14]}$ Furthermore, the presentation of the lesion may correlate with the location of the lesion in the talus. The localization of the neck of the talus leads to a limitation of movement, while the posterior side of the talus may lead to limited ankle extension and high fracture risk. Besides, the subtalar joint location of the lesion leads to functional subtalar synostosis and intraarticular loose body may cause chronic pain and limitation of movement. ${ }^{[6]}$

The differential diagnosis of a bone swelling clinically and radiologically detected at this location includes heterotopic ossification, reactive fluoride periostitis, Nora's lesion, and Trevor's disease. [14,17] Heterotopic ossification or post-traumatic ossification is a rare cause of joint stiffness. It occurs when the joint is seriously injured, particularly when the capsule and periosteum are stripped from the bone. In general, the degree of ossification is inversely proportional to the age of the patient, so that the most serious ossification occurs in children and young adults. Fluoride reactive periostitis is a rare benign bone lesion affecting the fingers or toes of adolescents and young adults. Although 
the cause is unknown, approximately half of the patients have a history of trauma. Clinically, a progressive swelling, erythema, and painful mass are seen in the affected part. Bizarre parosteal osteochondromatous proliferation (BPOP) or Nora's lesion is a rare benign tumor that affects the hand and foot bones in young adults. Bizarre parosteal osteochondromatous proliferation typically occurs with a painless or mild painful mass that grows between weeks and months. ${ }^{[17]}$ In the differential diagnosis of osteochondromas from these diseases, the presence of cortex and spongiosa continuity between host bone and mass on radiological examination is very valuable for diagnosis. ${ }^{[4,8,14]}$ In our study, computed tomography and MRI methods were valuable to demonstrate the continuity of the cartilaginous head (which cannot be visualized directly by radiograph) and the cortex medulla (Figures 1 and 2).

Also, clinicians should be aware of Trevor's disease (dysplasia epiphysealis hemimelica) when evaluating a growing mass around the ankle in children and adolescents. Trevor's disease is a developmental abnormality of epiphyseal growth that affects one or more epiphysis. It is impossible to distinguish Trevor's disease from osteochondroma clinically and pathologically. The most important distinguishing feature of Trevor's disease is the pineal lesion in radiological evaluation. ${ }^{[14]}$

Treatment for osteochondromas should start by pursuing the presence of similar lesions, evaluating the genetic inheritance, and determining the history and physical examination in order to rule out the features requiring surgery. Since most of these lesions are benign and painless, clinical and direct radiographic follow-up are sufficient. ${ }^{[18,19]}$ Indications for surgery include pain and fractures due to crashing, restriction of joint movement, cosmetic or severe malformation, and suspected malignant transformation. ${ }^{[14,19,20]}$

The risk for malignant transformation is less than $1 \%$ in solitary osteochondromas. However, it has a malignancy risk of $10 \%$ when it is associated with genetic mutations, as observed in MHE. ${ }^{[1,5,6,19]}$ Malignant degeneration results in a low degree peripheral chondrosarcoma managed with complete surgical resection. ${ }^{[9,14,19,21]}$
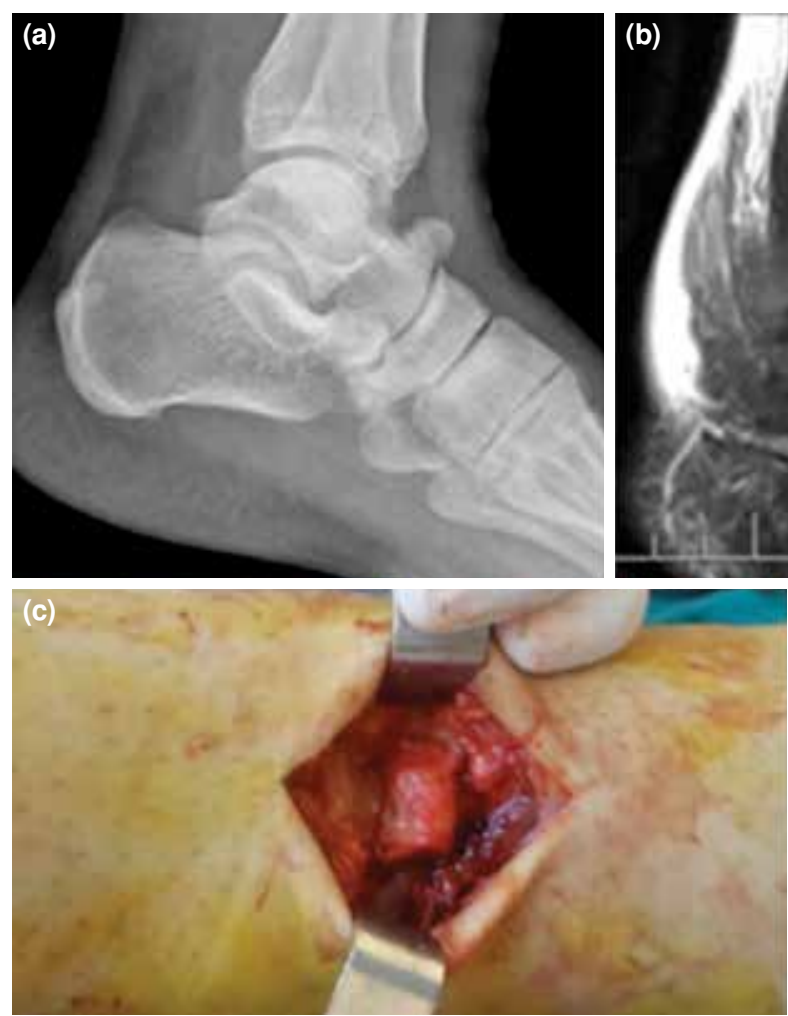

Figure 1. (a, b) Talus neck localized osteochondroma is visualized by direct radiography and magnetic resonance imaging (c) exposing the lesion from surrounding soft tissues (d) extraperiosteal complete excision of lesion.
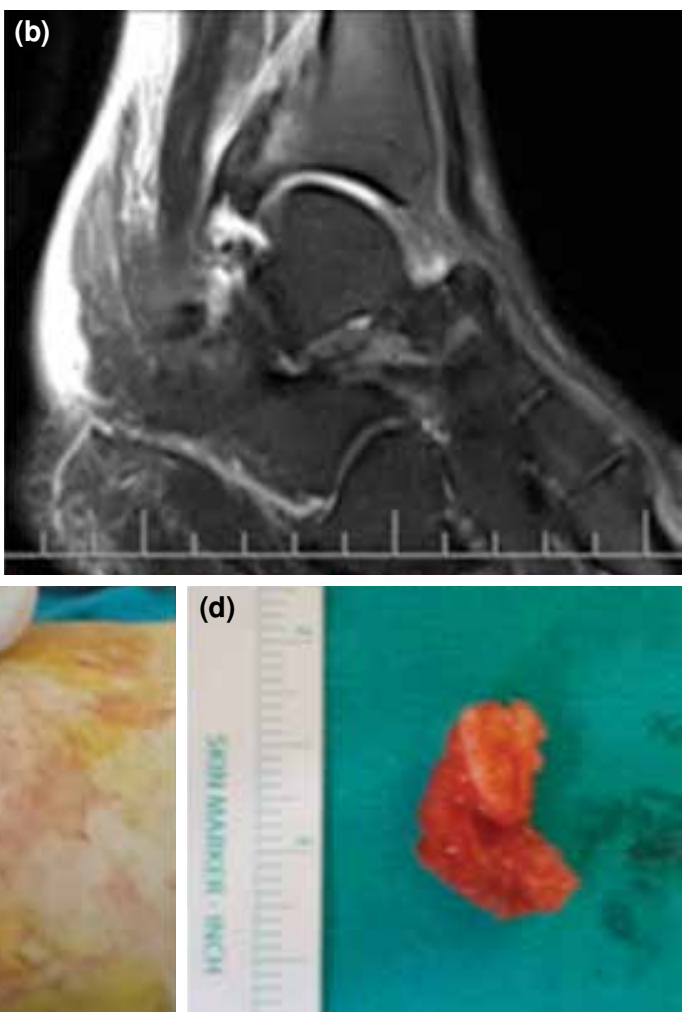

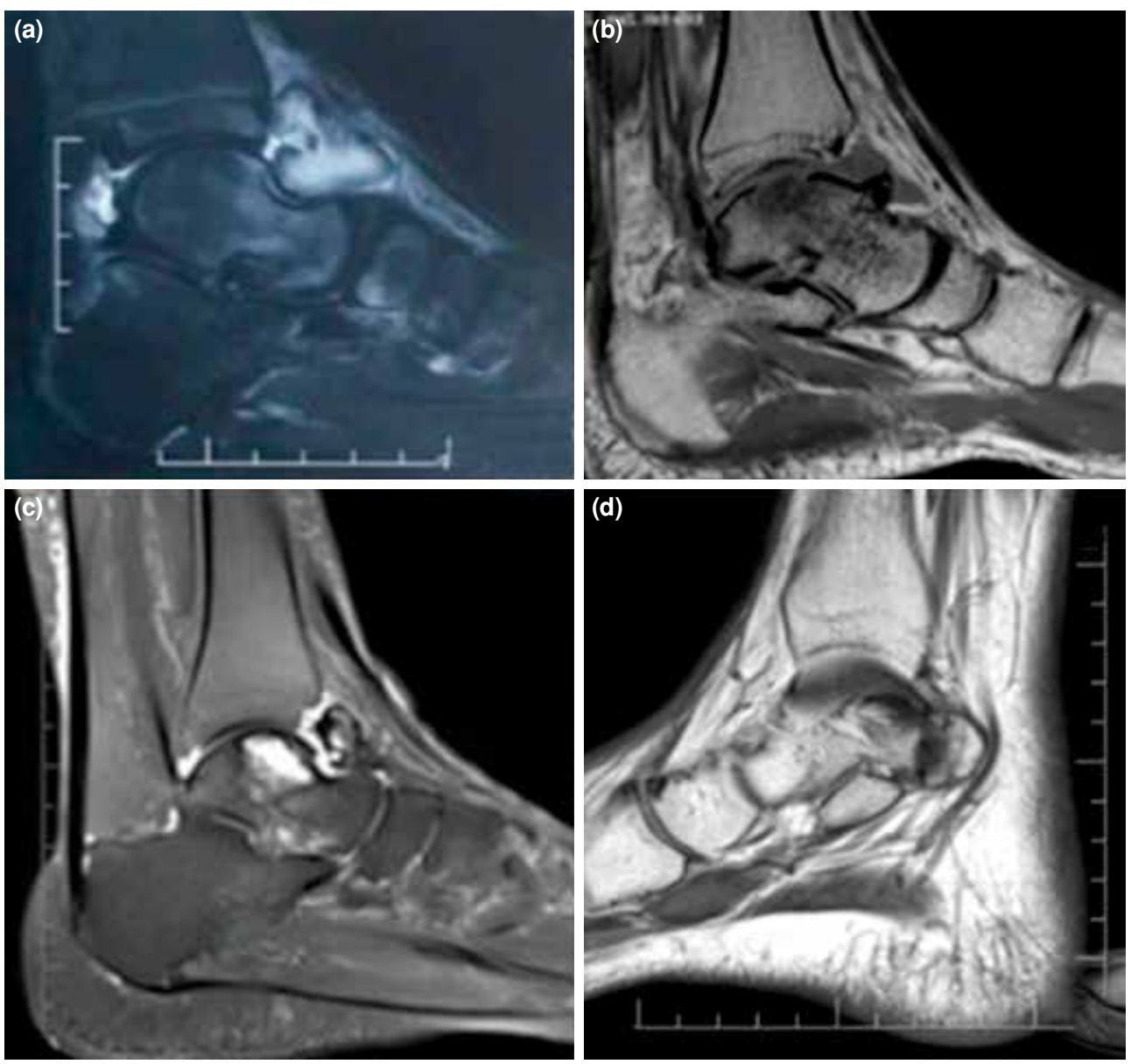

Figure 2. (a) Magnetic resonance imaging of anterior talus localized osteochondroma (b) talus neck localized osteochondroma accompanied by osteochondral defect (c) talus neck localized osteochondroma accompanied by additional talus localized simple bone cyst (d) talus posteromedial localized osteochondroma.

It has been reported that the postoperative recurrence rate is $1-2 \%$ in osteochondromas. In our study, no recurrence was encountered. The lack of removal of the entire cartilaginous or underlying periosteum is among the most common causes of recurrence. A second surgery may be necessary in case of symptomatic recurrence and suspected malignancy. ${ }^{[14,20]}$

This study has some limitations such as being a single hospital experience and a retrospective study, including a general assessment of a small group of patients.

In conclusion, unlike the general characteristics of osteochondromas, talus localized osteochondromas are symptomatic and common in adults. Also, they are more common in females than in males. The ideal treatment approach is resection of the tumor in all symptomatic cases.
The precise surgical excision of the tumor with the resection of the cartilage cover is important in reducing recurrence. When the tumor excision is performed adequately, recurrence rates are low and the outcomes are satisfactory.

\section{Declaration of conflicting interests}

The authors declared no conflicts of interest with respect to the authorship and/or publication of this article.

\section{Funding}

The authors received no financial support for the research and/or authorship of this article.

\section{REFERENCES}

1. Joshi D, Kumar N, Singh D, Lal Y, Singh AK. Osteochondroma of the talus in a male adolescent. J Am Podiatr Med Assoc 2005;95:494-6.

2. Kawai A, Mitani S, Okuda K, Aoki K, Inoue H. Ankle tumor in a 5-year-old boy. Clin Orthop Relat Res 2003;406:308-16. 
3. Karakurum G, Oznur A, Atilla B. Bilateral peroneal tubercle osteochondroma of the calcaneus: case report. Foot Ankle Int 1998;19:259-61.

4. Erler K, Oguz E, Komurcu M, AtesalpS, Basbozkurt M. Ankle swelling in a 6-year-old boy with unusual presentation: report of a rare case. J Foot Ankle Surg 2003;42:235-9.

5. Al Mutani M, Mahmood A, Chandrasekar CR. Giant osteochondroma of the talar neck. Foot (Edinb) 2013;23:45-9.

6. Andreacchio A, Marengo L, Canavese F. Solitary osteochondroma of the sinus tarsi. J Pediatr Orthop B 2018;27:88-91.

7. Chioros PG, FrankelSL, Sidlow CJ. Unusual osteochondroma of the foot and ankle. J Foot Surg 1987;26:407-11.

8. Fuselier CO, Binning T, Kushner D, Kirchwehm WW, Rice JR, Hetherington V, et al. Solitary osteochondroma of the foot: an in-depth study with case reports J Foot Surg 1984;23:3-24.

9. Kulkarni U, Kulkarni A. Posterior talus osteochondroma a rare location, treated by posterior ankle arthroscopy. Foot Ankle Surg 2015;21:e51-4

10. Murphey MD, Choi JJ, Kransdorf MJ, Flemming DJ, Gannon FH. Imaging of osteochondroma: variants and complications with radiologic-pathologic correlation. Radiographics 2000;20:1407-34.

11. Suranigi S, Rengasamy K, Najimudeen S, Gnanadoss J. Extensive Osteochondroma of Talus Presenting as Tarsal Tunnel Syndrome: Report of a case and Literature Review. Arch Bone Jt Surg 2016;4:269-72.

12. Atik OS, Sarikaya B, Kunat C, Muradi R, Ocaktan B,
Topçu H. Osteochondroma of the talus. Eklem Hastalik Cerrahisi 2010;21:116-7.

13. Unni KK. Osteochondroma. In: Unni KK, Inwards CY, editors. Dahlin's bone tumors: general aspects and data on 10,165 cases. 6th ed. Philadelphia: Wolters Kluwer: Lippincott Williams \& Wilkins; 2009.

14. Boya H, Ozcan O, Tokyol C. Osteochondroma of the talus: an unusual location. Acta Orthop Traumatol Turc 2014;48:236-9.

15. Keser S, Bayar A. Osteochondroma of the talar neck: a rare cause of callosity of the foot dorsum. J Am Podiatr Med Assoc 2005;95:295-7.

16. Atik OŞ. Which articles do we prefer to publish? Eklem Hastalik Cerrahisi 2018;29:1.

17. An V. An Unusual Swelling at Ankle: An Osteochondroma in Adult? Int J Clin Pract 2013;23:65-8.

18. Suranigi S, Rengasamy K, Najimudeen S, Gnanadoss J. Extensive Osteochondroma of Talus Presenting as Tarsal Tunnel Syndrome: Report of a case and Literature Review Arch Bone Jt Surg 2016;4:269-72.

19. Ozturk R. Bone and soft tissue tumors. 1st ed. Ankara: Derman Tibbi Yayıncılık; 2015.

20. Bottner F, Rodl R, Kordish I, Winklemann W, Gosheger G, Lindner N. Surgical treatment of symptomatic osteochondroma. A three- to eight-year follow-up study. J Bone Joint Surg [Br] 2003;85:1161-5.

21. Ahmed AR, Tan TS, Unni KK, Collins MS, Wenger DE, Sim FH. Secondary chondrosarcoma in osteochondroma: report of 107 patients. Clin Orthop Relat Res. 2003;411:193-206. 